\title{
Ocena zdolności separacji i integracji słuchowej: podstawy teoretyczne, dostępne testy - przegląd literatury
}

\section{Assessment of auditory integration and separation: theoretical basis, available tests - a review}

\author{
Karolina Dajos-Krawczyńska \\ Instytut Fizjologii i Patologii Słuchu, Światowe Centrum Słuchu, Warszawa/Kajetany \\ Adres autora: Karolina Dajos-Krawczyńska, Światowe Centrum Słuchu, Kajetany, ul. Mokra 17, \\ 05-830 Nadarzyn, e-mail: k.dajos@gmail.com
}

\begin{abstract}
Streszczenie
Umiejętność słuchania rozdzielnousznego jest jedną z podstawowych zdolności układu słuchowego, która umożliwia człowiekowi integrację i separację różnych sygnałów akustycznych docierających do obojga uszu w tym samym czasie. Do oceny umiejętności integracji i separacji słuchowej służą między innymi testy psychoakustyczne - testy słuchania rozdzielnousznego, w których stosowane są różnego rodzaju bodźce werbalne (sylaby, słowa, cyfry, zdania) i niewerbalne (tony, melodie). Testy rozdzielnouszne pozwalają również na ocenę procesów uwagi i pamięci krótkotrwałej, a także lateralizacji słuchowej i dominacji półkulowej w zakresie przetwarzania bodźców dźwiękowych. Celem artykułu było przedstawienie podstaw teoretycznych umiejętności integracji i separacji słuchowej oraz omówienie powszechnie stosowanych testów werbalnych słuchania rozdzielnousznego.
\end{abstract}

Słowa kluczowe: słuchanie rozdzielnouszne $\bullet$ integracja słuchowa $\bullet$ separacja słuchowa $\bullet$ CAPD

\begin{abstract}
Dichotic listening is one of the basic skills of auditory system. It allows to integrate and separate different acoustical signals coming into both ears at the same time. To assess auditory integration and separation we use i.a. psychoacoustic tests - dichotic listening tests with different verbal (syllables, words, digits, sentences) and nonverbal sounds. Dichotic listening tests allow also to assess the attention and short-term memory, auditory lateralization and hemispheric dominance in the processing of auditory stimuli. The aim of the article was to present the theoretical basis of auditory integration and separation, as well as discuss commonly used dichotic listening tests.
\end{abstract}

Key words: dichotic listening • auditory integration • auditory separation • CAPD

\section{Wprowadzenie}

Pojęcie integracji słuchowej oznacza zdolność do łączenia różnych bodźców akustycznych prezentowanych jednocześnie do obojga uszu w jedno zdarzenie akustyczne, natomiast pojęcie separacji słuchowej odnosi się do zdolności rozdzielania bodźców dźwiękowych docierających jednocześnie do obojga uszu. Integracja i separacja słuchowa składają się na tzw. „słuchanie rozdzielnouszne” (ang. dichotic listening).

Metodę słuchania rozdzielnousznego jako pierwszy opracował Broadbent w 1954 roku, w celu symulacji zjawiska „przeładowania uwagi” (ang. attention overload) u kontrolerów ruchu lotniczego. Kimura (1961) zastosowała tę metodę w badaniach funkcji półkulowych u osób zdrowych i u osób z uszkodzeniami mózgu, natomiast Bryden i wsp. (1983) zastosowali metodę rozdzielnousznego słuchania do badania procesów uwagi (uwaga uważana za źródło błędów). Dopiero w późniejszych latach Hugdahl wskazał, że badanie uwagi ukierunkowanej może być użyteczne w badaniach interakcji uwagi i lateralizacji [1].

Określenie „rozdzielnouszne” odnosi się do sposobu prezentacji bodźca - dwa różne bodźce dźwiękowe prezentowane są jednocześnie do obojga uszu - jeden do ucha prawego, natomiast drugi do ucha lewego [2,3]. W testach rozdzielnousznych używane są zarówno bodźce językowe, jak i niejęzykowe (np. tony). W diagnostyce klinicznej najczęściej używane są testy z użyciem bodźców słownych, dlatego też w niniejszej pracy dokonano opisu technik i metod stosowanych w badaniu integracji i separacji słuchowej z zastosowaniem bodźców werbalnych. W pierwszej części pracy przedstawiono podstawy teoretyczne 
dotyczące niniejszego zagadnienia, natomiast w drugiej części metody i techniki badawcze stosowane powszechnie $\mathrm{w}$ badaniach klinicznych i eksperymentalnych.

\section{Teorie przewagi ucha prawego}

Zastosowanie bodźców językowych powoduje zazwyczaj powstanie tzw. przewagi ucha prawego (ang. right ear advantage, REA), co oznacza, że więcej prawidłowych odpowiedzi uzyskuje się dla bodźców docierających do prawego ucha, natomiast zdecydowanie mniej prawidłowych odpowiedzi dla bodźców docierających do ucha lewego [3].

Powstawanie przewagi ucha prawego częściowo wyjaśnia tzw. teoria anatomiczna [4], która zakłada, że spowodowana jest ona przede wszystkim budową anatomiczną układu słuchowego i nadrzędnością lewej półkuli mózgu w przetwarzaniu bodźców językowych [1]. Zakłada się, że u większości ludzi przetwarzanie językowe odbywa się głównie w lewej półkuli. Badania Brancha i wsp. (1964) wykazały, że u $90 \%$ osób praworęcznych i $60 \%$ osób leworęcznych reprezentacje funkcji językowych znajdują się w lewej półkuli [za: 4]. Większość osób osiąga również lepsze wyniki w uchu prawym w badaniach rozdzielnousznych. Zatem, dla większości ludzi, kontralateralne projekcje słuchowe z prawego ucha do lewej półkuli mózgu muszą być $\mathrm{w}$ jakiś sposób nadrzędne $\mathrm{w}$ porównaniu $\mathrm{z}$ ipsilateralnymi projekcjami słuchowymi z lewego ucha [5]. W czasie słuchania rozdzielnousznego bodźce ipsilateralne są prawdopodobnie hamowane lub nawet całkowicie blokowane, co powoduje, że bodźce z projekcji kontralateralnych są przenoszone i przetwarzane bardziej efektywnie. Mechanizm blokowania projekcji ipsilateralnych pozostaje jednak niejasny [5].

Informacje słuchowe $\mathrm{z}$ lewego ucha, docierające najpierw do prawej półkuli mózgu, w celu przetworzenia muszą zostać przetransportowane do lewej półkuli. Badania obrazowe wskazują, że w przekazywaniu sygnałów z lewego ucha do lewej półkuli mózgu istotną rolę odgrywa ciało modzelowate. Jest ono aktywne również w czasie ukierunkowywania uwagi na bodźce dochodzące $z$ ucha lewego [2]. Konieczność transferu części informacji przez ciało modzelowate powoduje opóźnienie w przetwarzaniu bodźców docierających z ucha lewego, co z kolei może przyczyniać się do powstawania przewagi ucha prawego. Udział ciała modzelowatego w powstawaniu REA potwierdzają również badania u osób z uszkodzeniami ciała modzelowatego [6].

Na powstawanie przewagi ucha prawego wpływ mogą mieć także asymetrie $\mathrm{w}$ funkcjonowaniu ślimaka i pnia mózgu (w uchu prawym obserwuje się większe amplitudy otoemisji akustycznych wywołanych trzaskiem, a u noworodków odpowiedzi pnia mózgu po stronie prawej charakteryzują się większą amplitudą i krótszą latencją). Chociaż strukturalne asymetrie na niższych poziomach układu słuchowego nie są bezpośrednio powiązane $\mathrm{z}$ przewagą ucha prawego w badaniach rozdzielnousznych, sugerują jednak, że przetwarzanie informacji docierających do prawego ucha jest „preferowane” [za: 5,7].

Powstawanie przewagi ucha prawego dla bodźców słownych wyjaśnić można również za pomocą tzw. teorii „podwójnego filtrowania częstotliwości”, według której bodźce dźwiękowe poddawane są filtracji na dwóch poziomach. Na pierwszym poziomie zachodzi symetryczne obuuszne filtrowanie, podczas którego „wybierane” są informacje zawarte w takim zakresie częstotliwości, który będzie istotny dla dalszego przetwarzania. Na drugim poziomie, bodźce, które mają być przetwarzane w lewej półkuli, są poddawane filtrowaniu górnoprzepustowemu, natomiast bodźce przetwarzane w prawej półkuli filtrowaniu dolnoprzepustowemu. W konsekwencji, w lewej półkuli przetwarzane są bodźce o wyższych częstotliwościach, natomiast w prawej bodźce o niskich częstotliwościach. Według tej teorii przetwarzanie bodźców językowych odbywa się głównie w lewej półkuli, w związku z względnie wysoką częstotliwością dźwięków mowy. Poparciem tej teorii są badania nad asymetrią percepcji wysokości, z których wynika, że bodźce wysokoczęstotliwościowe powodują przewagę ucha prawego, natomiast niskoczęstotliwościowe przewagę ucha lewego [za: 5].

Kolejną teorią wyjaśniającą powstawanie przewagi ucha prawego jest tzw. teoria „uwagi”, opracowana przez Kinsbourne’a w latach 70. XX w. Podstawą tej teorii jest założenie, że istnieje dynamiczna nierównowaga pobudzenia półkul mózgowych - bodźce językowe powodują większą aktywację lewej półkuli, co z kolei prowadzi do skierowania uwagi na bodźce docierające $\mathrm{z}$ kontralateralnej strony (prawej). Teoria Kinsbourne’a znalazła poparcie w badaniach obrazowych w dziedzinie wzroku - badania te wykazały aktywację obszaru pól wzrokowych po lewej stronie podczas słuchania rozdzielnousznego [8]. Badania słuchania rozdzielnousznego dowiodły, że asymetria słuchowa może zostać zmieniona lub nawet odwrócona przez zmianę kierunku uwagi osoby badanej [za: 5] bądź też przez oczekiwanie pojawienia się bodźca werbalnego lub niewerbalnego [9].

Po ukierunkowaniu uwagi na ucho prawe znacznie zmniejsza się liczba prawidłowych odpowiedzi z ucha lewego, natomiast liczba poprawnych odpowiedzi z ucha prawego zwiększa się jedynie nieznacznie. $Z$ kolei ukierunkowanie uwagi na ucho lewe powoduje zmniejszenie odpowiedzi $\mathrm{z}$ ucha prawego i znaczny przyrost liczby prawidłowych odpowiedzi z ucha lewego. Sugeruje się, że poprawa wyniku w uchu ze skierowaną uwagą spowodowana jest prawdopodobnie większym hamowaniem przetwarzania przez układ słuchowy bodźców z ucha przeciwnego [10]. Obecność odpowiedzi $\mathrm{z}$ lewego ucha $\mathrm{w}$ warunkach uwagi rozproszonej wskazuje, iż informacje docierające $z$ obojga uszu są przetwarzane równocześnie, choć te $\mathrm{z}$ ucha ipsilateralnego są przetwarzane wolniej i w mniejszym zakresie [10].

Kompus i wsp. [11] sugerują, że badanie z ukierunkowaniem uwagi na ucho lewe wymaga większego zaangażowania procesów poznawczych w celu „przezwyciężenia” tendencji do podawania odpowiedzi na bodźce docierające $\mathrm{z}$ ucha prawego [11]. Prowadzone przez autorów badania obrazowe fMRI potwierdzają, że przetwarzanie bodźców docierających do lewego i prawego ucha wymaga zaangażowania różnych procesów poznawczych [11].

Pomimo licznych badań potwierdzających zarówno teorie anatomiczne, jak i teorie uwagi, żaden $z$ tych modeli samodzielnie nie wyjaśnia w pełni zjawiska przewagi ucha prawego. Obecnie uważa się, że zarówno budowa strukturalna 
układu słuchowego, jak i procesy uwagi są w równym stopniu istotne w powstawaniu lateralizacji słuchowej [12].

\section{Lateralizacja słuchowa}

Występowanie przewagi ucha prawego jest dowodem na istnienie tzw. asymetrii słuchowej, związanej ze specjalizacją półkul mózgowych w przetwarzaniu sygnałów akustycznych. Badania obrazowe wykazały, że lewa półkula jest wyspecjalizowana w przetwarzaniu m.in. bodźców językowych, natomiast prawa półkula w przetwarzaniu tzw. całościowym (np. dźwięki muzyki, prozodia, dźwięki o nacechowaniu emocjonalnym) [13]. Asymetria słuchowa nieodłącznie związana jest $\mathrm{z}$ lateralizacją, która oznacza „przewagę stronną” lub też „preferencyjne użycie lub nadrzędną funkcję jednej części ciała” [za: 13].

Wielu autorów wskazuje, że proste określenie przewagi któregoś z uszu lub braku przewagi jest niewystarczające. Adekwatnym wskaźnikiem dominacji językowej jest tzw. stopień lateralizacji (ang. index of degree of lateralization). Jednym z najczęściej stosowanych rodzajów określania stopnia lateralizacji jest $\lambda$. Pomiar ten jest nieograniczony i ma prawie normalny rozkład, dlatego za jego pomoca można określić stopień lateralizacji i jego istotność [14].

W badaniach lateralizacji słuchowej za pomocą testów rozdzielnousznych należy wziąć pod uwagę czynniki związane $z$ osobą badaną, które mogą mieć istotny wpływ na wyniki, m.in. płeć oraz ręczność. Wpływ tych czynników na wyniki testów rozdzielnousznych analizowano w licznych pracach, jednak wyniki nie są jednoznaczne. Niektóre badania sugerują, że nie istnieją istotne różnice w lateralizacji słuchowej pomiędzy osobami prawo- i leworęcznymi, z kolei w innych pracach wykazano, że u osób leworęcznych przewaga ucha prawego jest znacznie mniejsza niż u osób praworęcznych, bądź też lateralizacja jest skierowana całkowicie w lewą stronę [za: 15]. Podobnie badania wpływu płci na wyniki testów rozdzielnousznych dają niejednoznaczne wyniki [15] - niektóre prace wskazują, że istnieją różnice pomiędzy kobietami i mężczyznami (lateralizacja u mężczyzn może być nieco większa niż $\mathrm{u}$ kobiet) [16], natomiast $\mathrm{w}$ innych nie stwierdzono istotnych różnic $[12,17]$.

Badania wykazały, że na lateralizację słuchową w istotny sposób wpływają również cechy akustyczne bodźca, m.in. intensywność. Identyfikacja bodźca prezentowanego do jednego ucha znacznie poprawia się, jeśli bodziec ten jest głośniejszy niż bodziec podawany do ucha przeciwnego $[3,18]$.

\section{Testy separacji i integracji słuchowej}

W ciągu kilkudziesięciu lat opracowano wiele testów słyszenia rozdzielnousznego, które różnią się między sobą przede wszystkim rodzajem zastosowanych bodźców (werbalne i niewerbalne), procedurą badania, rodzajem instrukcji dla osoby badanej, sposobem rejestracji wyników.

Biorąc pod uwagę procedurę badania, testy rozdzielnouszne możemy podzielić na:

- testy uwagi rozproszonej,
- testy uwagi ukierunkowanej na jedno z uszu (prawe bądź lewe).

Z procedurą badania ściśle związany jest rodzaj instrukcji dla pacjenta. $\mathrm{W}$ testach uwagi rozproszonej zadaniem pacjenta może być:

- podawanie wszystkich usłyszanych bodźców (niezależnie od ucha),

- podawanie wyłącznie tych bodźców, które osoba badana słyszała wyraźniej (nawet jeśli osoba badana słyszała również inne bodźce),

- podawanie wyłącznie tego bodźca, który był usłyszany jako pierwszy (nawet jeśli osoba badana słyszała również inne bodźce) [10].

W badaniu uwagi ukierunkowanej zadaniem pacjenta jest zazwyczaj podawanie odpowiedzi na bodźce docierające wyłącznie z ucha badanego, natomiast całkowite ignorowanie bodźców docierających do ucha niebadanego (nawet jeśli osoba badana je słyszy i rozumie).

W przypadku testów z użyciem bodźców werbalnych istnieją trzy rodzaje odpowiedzi, których może udzielić osoba badana:

- odpowiedzi na bodźce prezentowane do ucha kontralateralnego do półkuli dominującej w zakresie przetwarzania mowy (odpowiedzi poprawne),

- odpowiedzi na bodźce docierające do ucha ipsilateralnego do półkuli dominującej w zakresie przetwarzania mowy (odpowiedzi „wtrącone” - ang. intrusive),

- odpowiedzi, które nie są związane z prezentowanym bodźcem - błędy pominięcia lub podawanie odpowiedzi innej niż bodźce docierające do obojga uszu [10].

Badania wykazały, że użycie różnych bodźców powoduje odmienne wyniki testów rozdzielnousznych. Zastosowanie bodźców językowych powoduje większą aktywację lewej półkuli mózgu i powstanie przewagi ucha prawego, natomiast zastosowanie bodźców niewerbalnych skutkuje zwiększeniem aktywności prawej półkuli i powstaniem przewagi ucha lewego [19]. Badania Spellacy'ego i Blumsteina [9] wykazały, iż już samo oczekiwanie bodźca werbalnego lub niewerbalnego powoduje odmienne wzorce aktywności ten sam bodziec dźwiękowy powodował powstanie przewagi ucha prawego, kiedy osoba badana spodziewała się bodźca językowego, i powstanie przewagi ucha lewego, kiedy osoba badana spodziewała się usłyszeć bodziec niewerbalny.

\section{Testy rozdzielnouszne sylabowe}

Sylaby otwarte typu CV (spółgłoska - samogłoska, ang. consonant - vowel syllables) są najczęściej stosowanym bodźcem w badaniach słuchania. Sylaby są krótkie i łatwe do zapamiętania, nie wymagają również od słuchacza wysokich umiejętności językowych. Ze względu na właściwości akustyczne są łatwiejsze w percepcji i kodowaniu niż pojedyncze samogłoski [za: 20]. Mogą być stosowane w różnych grupach słuchaczy, niezależnie od wieku. Niektórzy autorzy wskazują, że użycie bodźców sylabowych zapewnia najbardziej wiarygodną ocenę lateralizacji językowej [12]. Najczęściej używane są sylaby zawierające spółgłoski zwarte („,b”, „d”, „g”, „p”, „k”, ,t”) w połączeniu z samogłoską „a”. 
Badania z użyciem sylab są standardowo przeprowadzane $\mathrm{w}$ trzech warunkach uwagi: rozproszonej oraz ukierunkowanej na ucho prawe i lewe. W badaniach uwagi rozproszonej i ukierunkowanej na ucho prawe zwykle obserwuje się występowanie przewagi ucha prawego, natomiast w badaniach uwagi ukierunkowanej na ucho lewe - brak przewagi któregoś z uszu lub przewagę ucha lewego [10-12,15].

Badania Berlina i wsp. [21] wykazały, że sylaby ze spółgłoskami bezdźwięcznymi są znacznie lepiej zrozumiałe niż sylaby ze spółgłoskami dźwięcznymi.

Voyer i wsp. [20] w swojej pracy wykazali, że w przypadku badań rozdzielnousznych z użyciem sylab, miejsce artykulacji spółgłosek wpływa na wielkość i kierunek asymetrii percepcyjnych.

Wiens i wsp. [22] prowadzili badania $\mathrm{z}$ użyciem sylab syntetyzowanych, a nie naturalnej mowy. Testy wykazały, że bodźce syntetyzowane są mniej podatne na wpływ uwagi $\mathrm{w}$ porównaniu $\mathrm{z}$ naturalną mową.

Foundas i wsp. [15] prowadzili badania $\mathrm{z}$ użyciem sylab $\mathrm{CV}$ w grupie osób dorosłych prawo- i leworęcznych. W badaniu uwagi rozproszonej w obu grupach wykazano przewagę ucha prawego, jednak w grupie osób praworęcznych asymetrie słuchowe były bardziej wyraźne. Autorzy badali również interakcję pomiędzy ręcznością a przewagą ucha - związek pomiędzy uwagą i zmianą lateralizacji miał odmienny wzór u osób prawo- i leworęcznych. W badaniu uwagi rozproszonej liczba prawidłowych odpowiedzi na bodźce docierające $z$ ucha lewego była dużo większa u osób z silną lewostronną lateralizacją ręki, co może sugerować dominację prawej półkuli mózgu w zakresie przetwarzania bodźców językowych u tych osób [15].

\section{Testy rozdzielnouszne cyfrowe}

Równie często w badaniach rozdzielnousznych stosowane są bodźce cyfrowe. Cyfry są stosunkowo dobrze znane większości słuchaczy, są również łatwe do zapamiętania i rozróżnienia - $\mathrm{z}$ tego powodu mogą być stosowane w różnych grupach badawczych, bez względu na wiek. Wykazano również, że rozumienie cyfr jest względnie niezależne od ubytków słuchu, dzięki czemu bodźce te mogą być stosowane także u osób niesłyszących [23]. Najczęściej stosowane są cyfry w zakresie od 1 do 10 (często $\mathrm{z}$ wykluczeniem cyfry „7" - w języku angielskim jest to jedyna dwusylabowa cyfra w tym zakresie) [24,25], ale w niektórych badaniach używane są również liczby dwucyfrowe - np. w zakresie od 21 do 98 [26].

W badaniach rozdzielnousznych z użyciem cyfr również obserwowane jest występowanie zjawiska przewagi ucha prawego $\mathrm{w}$ testach uwagi rozproszonej i ukierunkowanej na ucho prawe, a także występowanie przewagi ucha lewego lub brak przewagi któregoś z uszu w testach uwagi ukierunkowanej na ucho lewe [25,27-30]. Dodatkowo, wyniki w uchu lewym były bardziej zmienne niż w uchu prawym [31].

Testy rozdzielnouszne z użyciem cyfr często przeprowadzane są z użyciem więcej niż jednej pary liczb - prezentowane są dwie, trzy lub cztery pary cyfr. Geffen i wsp. [27] badali dzieci w wieku 6-10 lat za pomocą testu rozdzielnousznego z użyciem 1, 2, 3 i 4 par cyfr. Niezależnie od wieku, im więcej prezentowano cyfr, tym mniej prawidłowych odpowiedzi rejestrowano. Zależność ta dotyczyła zarówno ucha prawego, jak i lewego [27]. Podobnie w badaniu Moncrieff i wsp. [31] z użyciem jednej, dwóch i trzech par cyfr wykazano, że zwiększanie liczby prezentowanych par powoduje zmniejszenie liczby prawidłowych odpowiedzi.

\section{Testy rozdzielnouszne słowne}

W testach rozdzielnousznych wykorzystuje się również bodźce słowne - są to najczęściej słowa jednosylabowe o konstrukcji CVC (spółgłoska - samogłoska - spółgłoska), rzadziej słowa wielosylabowe. W testach tych bardzo często stosuje się takie wyrazy, których budowa dźwiękowa różni się tylko dwiema głoskami w tej samej pozycji, głoski te zaś różnią się od siebie jedną cechą dystynktywną (np. dźwięcznością: [dok]: [tok]). Badania rozdzielnouszne $\mathrm{z}$ użyciem słów są nieco trudniejsze niż testy sylabowe lub cyfrowe, ponieważ wymagają większych zdolności językowych. Dodatkowo testy słowne mają dużo większy zakres możliwych „kombinacji” bodźców.

Podobnie jak w przypadku testów z użyciem sylab i cyfr, badania uwagi rozproszonej i ukierunkowanej na ucho prawe powodują zwykle powstanie przewagi ucha prawego, natomiast ukierunkowanie uwagi na ucho lewe skutkuje znacznym zmniejszeniem przewagi ucha prawego lub powstaniem przewagi ucha lewego $[28,32,33]$.

Jednym $\mathrm{z}$ rodzajów testów rozdzielnousznych $\mathrm{z}$ użyciem słów jest test tzw. słów rymowanych (ang. Fused Rhymed Test). Wexler i wsp. (1983) sugerowali, że podobieństwo w konturze wysokościowym sparowanych bodźców, podobnie jak inne nakładające się parametry akustyczne, powoduje "fuzję" dwóch bodźców w jedno zdarzenie akustyczne. Tendencja do łączenia dwóch bodźców w jeden percept w przypadku słów jest większa niż w przypadku sylab. Słowa rymowane mogą być więc bardziej użyteczne w badaniach uwagi, ponieważ słuchacz, który słyszy pojedynczy bodziec, jest prawdopodobnie mniej zdolny do kierowania uwagi na bodziec alternatywny [za: 22]. Badania Zatorre’a (1989) potwierdziły zgodność wyników testu słów rymowanych z badaniami lateralizacji językowej z użyciem próby amytalowej. Osoby, u których zaobserwowano przewagę ucha prawego, wykazały dominację lewej półkuli, natomiast osoby, u których zaobserwowano przewagę ucha lewego, wykazały dominację prawej półkuli mózgu. Badania te potwierdziły wysoką czułość testu z użyciem słów rymowanych na dominację półkulową w zakresie języka [za: 33].

Innym rodzajem testu rozdzielnousznego $\mathrm{z}$ użyciem słów jest Staggered Spondaic Word Test (SSW), w którym wykorzystywane są dwa słowa spondejowe (dwusylabowe), takie jak „do-mek”, „prze-jazd”, które prezentowane są jednocześnie. Słowa te nakładają się na siebie - druga sylaba jednego słowa jest prezentowana jednocześnie $\mathrm{z}$ pierwszą sylabą drugiego słowa. Zadaniem pacjenta jest powtórzenie usłyszanych słów [34].

Voyer i wsp. [35] prowadzili badania z użyciem 4 słów różniących się pierwszą głoską. Forma każdego z nich była nacechowana emocjonalnie (prozodia wyrażająca złość, 
szczęście, smutek, neutralność). Zadaniem pacjenta było wskazanie, jakie emocje były zawarte w prezentowanych słowach, bądź też określenie, czy w usłyszanych słowach występowało określone nacechowanie emocjonalne. Pomimo tego, że zastosowano bodźce słowne, wyniki wykazały występowanie przewagi ucha lewego, ponieważ zadaniem słuchacza było zwracanie uwagi na cechy prozodyczne wypowiedzi [35].

\section{Testy rozdzielnouszne zdaniowe}

Najrzadziej stosowane są testy rozdzielnouszne $\mathrm{z}$ użyciem zdań. Testy te są najtrudniejsze i wymagają dużego skupienia uwagi oraz większej znajomości języka. $Z$ tego powodu częściej wykonywane są u osób dorosłych niż u dzieci.

Przykładem testu z użyciem zdań jest test zdań konkurujących (ang. Compteing Sentence Test, CST), w którym do jednego ucha podawane jest jedno zdanie, natomiast do drugiego ucha inne zdanie o podwyższonym poziomie intensywności $(+15 \mathrm{~dB})$. Zadaniem osoby badanej jest powtórzenie tego zdania, które podawane jest ciszej, i ignorowanie zdania podawanego głośniej [34]. Nieprawidłowy wynik w teście CST zaobserwowano u pacjentów z uszkodzeniami płata skroniowego, głównie w uchu kontralateralnym do uszkodzenia.

Innym testem rozdzielnouszym z użyciem zdań jest test DSI (ang. Dichotic Sentence Identification), w którym jednocześnie do obojga uszu prezentowane są dwa zdania, natomiast zadaniem osoby badanej jest wskazanie, które z 6 zdań usłyszał [34]. Test ten jest czuły na deficyty integracji i separacji obuusznej związane $z$ wiekiem. Jerger i wsp. [36] wykazali, że wraz z wiekiem wzrasta przewaga ucha prawego (bądź zwiększa się deficyt ucha lewego), zarówno w przypadku badania uwagi rozproszonej, jak i ukierunkowanej. Badania Gatesa i wsp. [37] wykazały, że nieprawidłowości $\mathrm{w}$ testach przetwarzania słuchowego, m.in. w testach rozdzielnousznych zdaniowych, mogą być wczesnym objawem demencji lub obniżenia zdolności poznawczych.

\section{Powtarzalność testów rozdzielnousznego słyszenia}

Testy rozdzielnouszne są jedną z najpowszechniej stosowanych metod oceny lateralizacji językowej, zarówno w badaniach klinicznych, jak i naukowych. Jednak wiarygodność i powtarzalność tych testów jest przedmiotem dyskusji.

Uważa się, że testy diagnostyczne są powtarzalne, jeśli współczynnik korelacji osiągnie wartość $>0,8$ [25]. $\mathrm{W}$ pierwszych badaniach $\mathrm{z}$ użyciem testów rozdzielnousznych wykazano, że ich wyniki nie osiągają zalecanego współczynnika powtarzalności [5]. W badaniach obserwowano również wysoką zmienność wyników, pomimo wysokich wartości współczynników korelacji [38]. W późniejszych pracach dotyczących powtarzalności wyników testów rozdzielnousznych $\mathrm{z}$ użyciem różnych bodźców językowych obserwowano umiarkowaną lub wysoką powtarzalność [5,39].

W zestawie testów przesiewowych SCAN (ang. Screening Test for Auditory Processing Disorders) znajduje się test rozdzielnouszny słowny. Keith [40] oraz Amos i wsp. [41] wykazali, że wyniki tego testu są powtarzalne w stopniu umiarkowanym.

Russell i wsp. [42] oceniali powtarzalność testów rozdzielnousznych $\mathrm{z}$ użyciem słów i sylab. W przypadku bodźców sylabowych współczynnik korelacji wynosił 0,76 , natomiast dla bodźców słownych 0,51 .

Wysoką powtarzalnością odznaczają się testy rozdzielnouszne $\mathrm{z}$ użyciem cyfr. W wielu badaniach wykazano, że nie występują istotne różnice pomiędzy wynikami dwóch kolejnych badań [30,43]. Musiek i wsp. [44] w teście rozdzielnousznym z użyciem cyfr wyznaczyli współczynnik korelacji na poziomie 0,77 .

W niektórych pracach wykazano, że wysoką powtarzalnością odznaczają się tylko badania uwagi rozproszonej, natomiast badania uwagi ukierunkowanej nie osiągają zalecanego współczynnika korelacji [12,17].

W pracy Kochanka i wsp. [45] przeprowadzono ocenę powtarzalności testu rozdzielnousznego liczbowego u dzieci. Wyniki badań były powtarzalne, bez względu na wiek, badane ucho oraz uzyskany odsetek prawidłowych odpowiedzi.

\section{Testy rozdzielnouszne $w$ diagnostyce zaburzeń przetwarzania słuchowego}

Jerger i Musiek [46] wskazali, że testy rozdzielnouszne są jednym $z$ najistotniejszych elementów diagnostyki zaburzeń przetwarzania słuchowego. Badania wykazały, że testy słuchania rozdzielnousznego są czułe na uszkodzenia różnych poziomów ośrodkowego układu słuchowego. Niemal 50\% osób z uszkodzeniami ośrodkowego układu nerwowego w teście zdań konkurujących (CST) uzyskuje nieprawidłowe wyniki w uchu ipsilateralnym do miejsca uszkodzenia, natomiast osoby z uszkodzeniami płata skroniowego wykazują deficyty w uchu kontralateralnym [34]. Test rozdzielnouszny z użyciem słów spondejowych jest czuły na uszkodzenia korowe i uszkodzenia pnia mózgu [34]. Z kolei badania słuchania rozdzielnousznego z użyciem cyfr wykazały nieprawidłowe wyniki w uchu kontralateralnym w przypadku uszkodzenia prawego płata skroniowego, a także nieprawidłowe wyniki w obojgu uszach lub w uchu kontralateralnym w uszkodzeniach lewej półkuli mózgu. Słabsze wyniki w uchu lewym obserwowane są u pacjentów z deficytami międzypółkulowymi - są one znacznie częstsze niż w uchu prawym [34].

Vanniasegaram i wsp. [47] prowadzili badania rozdzielnouszne u dzieci z grupy ryzyka APD. Dzieci z grupy ryzyka w obojgu uszach uzyskują słabsze wyniki w porównaniu z grupą kontrolną. Yathiraj i wsp. [48] oceniali ośrodkowe funkcje słuchowe u dzieci w wieku 8-13 lat. Badaniami objęto m.in. 64 dzieci z grupy ryzyka zaburzeń przetwarzania słuchowego. 65,5\% dzieci z tej grupy miało nieprawidłowe wyniki testu słuchania rozdzielnousznego z zastosowaniem sylab CV. W badaniach Bellis i wsp. [24] uczestniczyły dzieci z zaburzeniami przetwarzania słuchowego i dzieci w normie. W obu grupach zaobserwowano przewagę ucha prawego, jednak u dzieci z ośrodkowymi zaburzeniami słuchowymi asymetria słuchowa (różnica pomiędzy wynikiem ucha prawego i lewego) była znacznie 
większa niż u dzieci z grupy kontrolnej [24]. Z kolei w badaniach Iliadou i wsp. [49] brały udział dzieci w normie, dzieci z CAPD oraz dzieci z dysleksją (bez objawów zaburzeń przetwarzania słuchowego). Dzieci z centralnymi zaburzeniami słuchu w obojgu uszach miały niższe wyniki niż dzieci w normie i dzieci z dysleksją. Dodatkowo $\mathrm{w}$ grupie dzieci z zaburzeniami przetwarzania słuchowego (oraz u dzieci z dysleksją) obserwowano większy odsetek dzieci z lateralizacją lewostronną [49].

Testy rozdzielnousznego słyszenia z użyciem bodźców słownych są istotnym elementem zestawów do badań przesiewowych ośrodkowych zaburzeń słuchu, m.in. opracowanego przez Keith'a testu SCAN (ang. Screening Test for Auditory Processing Disorders), w którym znajduje się test słów konkurujących (ang. Competing Word, CW). W zestawie MAPA (ang. Multiple Auditory Processing Assessment) znajdują się dwa werbalne testy rozdzielnouszne test liczbowy (ang. Dichotic Digit, DD) oraz słowny (ang. Competing Sentence, CS).

\section{Podsumowanie}

Badania eksperymentalne i kliniczne wskazują, że testy rozdzielnouszne z użyciem różnego rodzaju bodźców mogą być czułym i nieinwazyjnym narzędziem do badania lateralizacji językowej i słuchowej, ale także uwagi krótkoi długotrwałej, zmian kierunku uwagi, integracji międzypółkulowej i funkcji ciała modzelowatego czy dysfunkcji poznawczych w zaburzeniach neurodegeneracyjnych i psychicznych. Są również przydatne w badaniach funkcji słuchowych u osób z grupy ryzyka zaburzeń przetwarzania słuchowego. Możliwość zastosowania różnego rodzaju bodźców sprawia, że testy te są odpowiednie dla niemal każdej grupy wiekowej, a poziom trudności testu można dostosować do poziomu językowego i poznawczego osoby badanej.

Publikacja powstała $w$ związu $z$ realizacja projektu pn. „Zintegrowany system narzędzi do diagnostyki i telerehabilitacji schorzeń narządów zmystów (stuchu, wzroku, mowy, równowagi, smaku, powonienia)" INNOSENSE, wspótfinansowanego przez Narodowe Centrum Badań i Rozwoju w ramach Programu STRATEGMED.

\section{Piśmiennictwo:}

1. Hugdahl K. What can be learned about brain function from dichotic listening? Revista Espanola de Neuropsicologia, 2000; 2(3): $62-84$

2. Westerhausen R, Hugdahl K. The corpus callosum in dichotic listening studies of hemispheric asymmetry: A review of clinical and experimental evidence. Neurosci Biobehav Rev, 2008; 32: 1044-54.

3. Hugdahl $\mathrm{K}$. The effect of stimulus intensity on the right ear advantage in dichotic listening. Neurosci Lett, 2008; 431: 90-94.

4. Kimura D. Functional asymmetry of the brain in dichotic listening. Cortex, 1967; 3(2): 163-78.

5. Hiscock M, Kinsbourne M. Attention and the right-ear advantage: What is the connection? Brain Cogn, 2011; 76: 263-75.

6. Gootjes L, Van Strien JW, Bouma A. Age effects in identifying and localising dichotic stimuli: a corpus callosum deficit? J Clin Exp Neuropsychol, 2004; 26(6): 826-37.

7. Khalfa S. Evidence of peripheral hearing asymmetry in humans: clinical implications. Acta Otolaryngol (Stock's), 1998; 117: 192-96.

8. Thomsen T, Rimol LM, Ersland L, Hugdahl K. Dichotic listening reveals functional specificity in prefrontal cortex: An fMRI study. Neuroimage, 2004; 21: 211-18.

9. Spellacy F, Blumstein S. The influence of language set on ear preference in phoneme recognition. Cortex, 1970; 6(4): 430-39.

10. Asbojrnsen AE, Hughdal K. Attentional effects in dichotic listening. Brain Lang, 1995; 49: 189-201.

11. Kompus K, Specht K, Ersland L i wsp. A forced-attention dichotic listening fMRI study on 113 subjects. Brain Lang, 2012; 121: $240-47$.

12. Gadea M, Gomez C, Espert R. Test-Retest performance for the consonant-vowel dichotic listening test with and without attentional manipulations. J Clin Exp Neuropsychol, 2000; 22(6): 793-803.

13. Kurkowski ZM. Lateralizacja słuchowa a zaburzenia komunikacji językowej. Audiofonologia, 2002; 21: 179-86.

14. Grimshaw GM, McManus IC, Bryden MP. Controlling for stimulus dominance in dichotic listening tests: a modification of lambda. Neuropsychology, 1994; 8(2): 278-83.
15. Foundas AL, Corey DM, Hurley MM i wsp. Verbal dichotic listening in right and left-handed adults: Laterality effects of directed attention. Cortex, 2006; 42: 79-86.

16. Voyer D. Sex differences in dichotic listening. Brain Cogn, 2011; 75: 245-55.

17. Voyer D, Flight JI. Reliability and magnitude of auditory laterality effects: the influence of attention. Brain Cogn, 2001; 46: 397-413.

18. Westerhausen R, Moosmann M, Alho K, Medvedev S, Hämäläinen $\mathrm{H}$, Hugdahl K. Top-down and bottom-up interaction: manipulating the dichotic listening ear advantage. Brain Res, 2009; 1250: 183-89.

19. Jancke L, Buchanan TW, Lutz K, Shah NJ. Focused and nonfocused attention in verbal and emotional dichotic listening: an fMRI study. Brain Lang, 2001; 78: 349-63.

20. Voyer D. Dichotic listening with consonant-vowel pairs: the role of place of articulation and stimulus dominance. Journal of Phonetics, 2009; 37: 162-72.

21. Berlin CI, Hughes LF, Lowe-Bell SS, Berlin HL. Dichotic right ear advantage in children 5 to 13. Cortex, 1973; 9(4): 394-402.

22. Wiens S, Emmerich DS. Synthetic stimuli attenuate the effect of attention on the dichotic right-ear advantage. Acta Psychologica, 1999; 102: 13-19.

23. Zenker F, Mora Espino R, Marro Cosialls S i wsp. The effect of age over the dichotic digit test. $8^{\text {th }}$ EFAS Congress, $10^{\text {th }}$ Congress of the German Society of Audiology, 2007.

24. Bellis TJ, Billiet C, Ross J. Hemispheric lateralization of bilaterally presents homologous visual and auditory stimuli in normal adults, normal children, and children with central auditory dysfunction. Brain Cogn, 2008; 66: 280-89.

25. Carr BM. Ear effect variables and order of report in dichotic listening. Cortex, 1969; 5(1): 63-68.

26. Dos Santos Sequeira S, Specht K, Hämäläinen H, Hugdahl K. The effects of background noise on dichotic listening to consonant - vowel syllables. Brain Lang, 2008; 107: 11-15.

27. Geffen G. The development of the right ear advantage in dichotic listening with focused attention. Cortex, 1978; 14(2): $169-77$. 
28. Lamm O, Epstein R. Dichotic listening in children: the reflection of verbal and attentional changes with age. J Exp Child Psychol, 1997; 65: 25-42.

29. Moncrieff DW. Dichotic listening in children: Age-related changes in direction and magnitude of ear advantage. Brain Cogn, 2011; 76(2): 316-22.

30. Mukari SZ, Keith RW, Tharpe AM, Johnson CD. Development and standardization of single and double dichotic digit tests in Malay language. Int J Audiol, 2006; 45: 344-52.

31. Moncrieff DW, Wilson RH. Recognition of randomly presented one-, two-, and three-pair dichotic digits by children and young adults. J Am Acad Audiol, 2009; 20: 58-70.

32. Mohr E. Cognitive style and order of recall effects in dichotic listening. Cortex, 1987; 23: 223-36.

33. Shinn JB, Baran JA, Moncrieff DW, Musiek FE. Differential attention effects on dichotic listening. J Am Acad Audiol, 2005; 16: 205-18.

34. Mąka J. The Polish linguistic test review in the assessment of Central Auditory Processing Disorders. Investigationes Linguisticae, 2009; 18: 55-79.

35. Voyer D, Russell A, McKenna J. On the reliability of laterality effects in a dichotic emotion recognition task. J Clin Exp Neuropsychol, 2002; 24(5): 605-14.

36. Jerger J, Chmiel R, Allen J, Wilson A. Effects of age and gender on dichotic sentence identification. Ear Hear, 1994; 15(4): 274-86.

37. Gates GA, Anderson ML, McCurry SM. Central auditory dysfunction as a harbinger of Alzheimer dementia. Arch Otolaryngol Head Neck Surg, 2011; 137(4): 390-95.

38. Pizzamiglio L, De Pascalis C, Vignati A. Stability of Dichotic Listening Test. Cortex, 1974; 10(2): 203-5.
39. Hugdahl K. Fifty years of dichotic listening research - Still going and going and... Brain Cogn, 2011; 76(2): 211-13.

40. Keith RW. Development and standardization of the SCAN-C test for auditory processing disorders in children. J Am Acad Audiol, 2000; 11(8): 438-45.

41. Amos NE, Humes LE. Scan test-retest reliability for first and third-grade children. JSLHR, 1998; 41: 834-45.

42. Russell NL, Voyer D. Reliability of laterality effects in a dichotic listening task with words and syllables. Brain Cogn, 2004; 54: 266-76.

43. Frasca MFSS, Lobo IFN, Schochat E. Test and retest of auditory processing: reliability of the evaluation. Revista da Sociedade Brasileira de Fonoaudiologia, 2011; 16(1): 42-48.

44. Musiek FE, Gollegly KM, Kibbe KS, Verkest-Lenz SB. Proposed screening test for central auditory disorders: follow-up on the dichotic digits test. Am J Otol, 1991; 12(2): 109-13.

45. Kochanek K, Dajos-Krawczyńska K, Piłka A, Biegun K, Skarżyński H. Ocena powtarzalności testu rozdzielnousznego cyfrowego u dzieci w wieku szkolnym. Otorynolaryngologia przegląd kliniczny, 2015; 14(2): 79-88.

46. Jerger J, Musiek FE. Report of the consensus conference on the diagnosis of auditory processing disorders in school-aged children. J Am Acad Audiol, 2000; 11: 467-74.

47. Vanniasegaram I, Cohen M, Rosen S. Evaluation of selected auditory tests in school-age children suspected of auditory processing disorders. Ear Hear, 2004; 25(6): 586-97.

48. Yathiraj A, Maggu AR. Screening Test for Auditory Processing (STAP): a preliminary report. J Am Acad Audiol, 2013; 24(9): 867-78.

49. Iliadou V, Kaprinis S, Kandylis D, Kaprinis GS. Hemispheric laterality assessment with dichotic digits testing in dyslexia and auditory processing disorder. Int J Audiol, 2010; 49: 247-52. 